\title{
Assessing the Predictor Roles of Mindfulness and Spiritual Intelligence for Depressive and Anxiety Symptoms
}

\author{
Pınar Ünal-Aydın ${ }^{1}$ \\ International University of Sarajevo
}

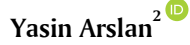 \\ International University of Sarajevo
}

\author{
Orkun $\mathrm{Aydin}^{3}$ \\ International University of Sarajevo
}

\footnotetext{
${ }^{1}$ Assist. Prof., MD, Department of Psychology, International University of Sarajevo, Sarajevo, Bosnia and Herzegovina. E-mail: paydin@ius.edu.ba

2 Scholarship Assistant, Department of Psychology, International University of Sarajevo, Sarajevo, Bosnia and Herzegovina. E-mail: arslanyasin@hotmail.com

${ }^{3}$ Assist. Prof., MD, Department of Psychology, International University of Sarajevo, Sarajevo, Bosnia and Herzegovina. E-mail: oaydin@ius.edu.ba
}

Corresponding author:

Orkun Aydin

E-mail:

oaydin@ius.edu.ba

eISSN: $2458-9675$

Received: 18.03 .2020

Revision: 28.09 .2020

Accepted: 05.10.2020

(C) Copyright 2020

by Author(s)

\begin{abstract}
The goal of this study was to examine the effects of mindfulness (MF) and spiritual intelligence (SI) as predictors of depression and anxiety, the most frequent manifestations of mental disorders - among 184 Turkish participants of diverse ages, predominantly students, living in Istanbul and Sarajevo. Four instruments were administered either directly or via web-based services: Scale for Spiritual Intelligence (SSI), Hospital anxiety and depression scale (HADS), Five Facet Mindfulness Questionnaire - Short Form (FFMQ-S) and Sociodemographic Information Form. Through the use of linear regression analysis, Actaware $(b=-.19, p \leq .001)$, Nonjudge $(b=-.22, p \leq .001)$, Nonreact $(b=-.19, p \leq .001)$ subscales of FFMQ-S were found to be negative predictors for depression and anxiety, whereas, Self-understanding subscale of SSI was not significant. Although our findings suggest that spiritual intelligence is not significant in prediction of depression and anxiety, our research provides empirical evidence for the link between MF, SI, depression and anxiety, as well as revealing MF as predictor for anxiety and depression which may be useful for further improvements in the scope of current interventions.

Keywords:
\end{abstract}

Mindfulness $\bullet$ Anxiety $\bullet$ Depression $\bullet$ Spiritual Intelligence $\bullet$ Mental health

Bilinçli Farkındalık ve Manevi Zekanın Depresyon ve Anksiyete Belirtileri Üzerindeki Rolünün Değerlendirilmesi

\section{Öz}

Bu çalşsmada Bilinçli Farkındalık ve Manevi Zekanın, en yaygın psikolojik durumlar olarak bilinen depresyon ve anksiyete üzerindeki etkisinin toplam 184 katılımcı - çeşitli yaşlardan olmakla beraber yoğunlukla öğrencilerden oluşan, İstanbul ve Saraybosna'da yaşayan, arasında incelenmesi amaçlanmıştır. Dört ölçek doğrudan veya web formları aracllğılyla uygulanmıştr: Manevi Zekâ Ölçeği, Hastane Anksiyete ve Depresyon (HAD) Ölçeği, Beş Faktörlı̈ Bilgece Farkındalık Ölçeği-Kısa Formu (BFBFÖ-K) ve Sosyodemografik Bilgi Formu. Bilinçli Farkındalık Ölçeğinin Dikkati Düzenleyebilme $(b=-.19, p \leq .001)$, Yarglamadan Gözleme ve İzleme $(b=-.22, p \leq .001)$, Etkilenmeden Gözleme ve İzleme $(b=-.19$, $\mathrm{p} \leq .001)$ alt boyutlarının depresyon ve anksiyete belirtilerini negatif yönde anlamlı olarak yordadı̆̆ bulunurken, Manevi Zeka ölçeğinin kendini anlama alt boyutu bu ilişki analizinde anlamsız bulunmuştur. Elde edilenlere göre, bu çalışma Bilinçli Farkındalık, depresyon ve kaygı arasındaki anlamılı ilişkinin ve bu ilişkide Manevi Zekanın rolünün anlaşııması için gelecek çalışmalara ışık tutmaktadır.

Anahtar Kelimeler:

Bilinçli Farkındalık • Anksiyete • Depresyon $\bullet$ Manevi Zeka $\bullet$ Ruh Sağlığı

Citation: Ünal-Aydın, P., Arslan, Y., \& Aydın, O. (2020). Assessing the predictor roles of mindfulness and spiritual intelligence for depressive and anxiety symptoms. Spiritual Psychology and Counseling, 5, 273-285. https://dx.doi.org/10.37898/spc.2020.5.3.103 
In recent years, there has been an increasing interest in mindfulness (MF), suggesting alternative techniques and conceptualization of it as an integrated part of psychotherapy strategies. (Academic Mindfulness Interest Group, 2006). While a variety of definitions of mindfulness have been suggested, we find it useful to consider the operational definition suggested by (Bishop et al., 2004) who defined it through two main components involving 'present' participation, (i) self-regulation of attention enabling enhanced identification of present mental process, (ii) orientation to experience particular commitment to one's own experiences toward current events, classified by curiosity, openness and acceptance. Several other definitions suggested as ability to direct attention or shift focus in particular (i) with an aim, (ii) at a given moment, (iii) with nonjudgmental acceptance of self-experience. In contemporary psychology, it is based on the framework of mental training which aims to equip individuals with certain skills and present moment awareness to reduce vulnerability to psychopathology - by lowering the effects of psychological distress and abnormal behavior. However, several studies suggest different effects for MF among nonmeditators with no prior meditation experience and/or knowledge in comparison to those meditators with past meditation experience, as well as potentially differing among meditators following different styles in their practice (Cardaciotto et al., 2008). Besides, it is worthwhile to consider several studies in this context, for instance, a recent longitudinal study based on students' academic stress and symptoms of depression shows that there is a negative correlation between depression and mindfulness, which may be counteractively functional against rumination (Barnes \& Lynn, 2010). On top of that, a study has confirmed that regular participation in mindfulness activities have shown to be negatively correlated with the difficulty ignoring the frequency and perception of negative automatic thoughts (Frewen et al., 2008)de-centered, and non-attached ways. However, empirical research has not examined associations between mindfulness and responses to negative automatic thoughts, such as the ability to let go of negative cognition. In the first study reported in this article, measures of dispositional mindfulness were negatively correlated with negative thought frequency and perceptions of the ability to let go of negative thoughts in an unselected student sample. In the second study reported, these associations were replicated in a treatment-seeking student sample, where participation in a mindfulness meditation-based clinical intervention was shown to be associated with decreases in both frequency and perceptions of difficulty in letting-go of negative automatic thoughts (Frewen et al., 2008).

Since $90 \%$ of people in the world practices some sort of spiritual activities, Spiritual Intelligence (SI) is another concept — defined as conscious awareness that manifests one's potential of vision, purpose and value, recently striking considerable attention from scientific community (Koenig, 2009). On top of that, some other preliminary works have primarily focused on developing the definition, for instance, 5 main 
subdimensions as consciousness, transcendence, grace, meaning and truth (Amram $\&$ Dryer, 2008). An increase in SI was later noted among mental health researchers due to its association with coping mechanisms and even certain psychopathological conditions (e.g., depression) (Ebrahimi et al., 2012). Yet only a few researchers addressed the question of SI in the context of mental health despite the evident benefit of spiritual practices for anxiety (Hofmann et al., 2016), regulating mood via increased GABA levels (Streeter et al., 2010), enhancing cognitive skills (e.g., executive functions) (Gothe, N., Pontifex, M. B., Hillman, C., \& McAuley, 2013).

Anxiety can be defined as the anticipation of physiological and psychological course ahead of a potential threat (American Psychiatric Association, 2013), a very common mental health issue across the globe, for instance; the prevalence of anxiety disorders are the highest in the U.S., affecting $18.1 \%$ of the population (Bandelow \& Michaelis, 2015). Another common condition is depression - a representation of various symptoms including sadness, irritability emptiness in addition to certain cognitive and somatic signs that impact one's capacity to function (American Psychiatric Association, 2013), revealed to be one of the most common mental health problems in global population (Vos et al., 2015). With these in mind, researches with various populations have shown that $70 \%$ of individuals with depressive signs also display anxiety symptoms, indicating high comorbidity in between (Wu \& Fang, 2014) - often derived from similar dysfunctional patterns in cognition (e.g., executive function) (Castaneda et al., 2008)Although there are number of researches examining the effects of spiritual practices on anxiety and depression separately, a clear understanding on the association of SI and MF with anxiety and depressive symptoms is lacking. A study has found that depression and anxiety are strongly linked with greater cognitive dysfunctional patterns (Airaksinen et al., 2004). Interventions based on MF - involving with spiritual practices, display promising results in improving neurobiological mechanisms of cognitive capacity (e.g., executive function) (Tang et al., 2012). In addition, numerous studies support MF as improving overall cognitive functioning; memory (Jha et al., 2007), sustained attention (Chambers et al., 2008), visual coding and verbal fluency (Zeidan et al., 2010), therefore understanding the aspects of MF and SI might be helpful to offer strategies for prevention of depression and anxiety.

Our hypotheses were (i) those with higher MF have lower symptoms of depression and anxiety, (ii) those with higher SI have lower symptoms of depression and anxiety, (iii) and higher SI is associated with higher mindfulness activity. 


\section{Materials and Methods}

\section{Participants}

One hundred and ninety individuals were recruited for the study with a convenience sampling method. To recruit participants, we posted an advertisement on the internet and published an announcement on social media platforms. The inclusion of participants was based on 3 characteristics; those (i) between 18-65 years of age, (ii) with no cognitive deficits that may prevent from filling up presented instruments, (iii) with no record of psychiatric disorders. Individuals with any kind of psychiatric disorder were excluded based on the self-report information and medical registries provided by participants. Six participants were dropped due to the presence of mental disorder. Ultimately, statistical analyses were performed with 184 participants. The participants were asked to participate in the research willingly which may last for 15 minutes approximately, those who accepted were either be introduced to hardcopy of scales, or, had access to our research scales on web-based questionnaires, which was distributed via links over social platforms. All the participants were informed about their right to withdraw their participation at any time without the risk of penalty and they provided written informed consent.

\section{Instruments}

Sociodemographic information Form. This instrument is designed to collect data about participant information with regards to the variables that we included in our study. It is composed of 9 items, each valued in basic numbers. These 9 items involve questions about age, gender, residence, employment status, education level, psychiatric diagnosis, frequency of meditative habits, and frequency of physical exercise on weekly basis. It collects overall demographic information of participants in addition to particular questions related to mindful activities, hobbies and how frequently these actions are employed on regular basis.

Five Facet Mindfulness Questionnaire - Short Form (FFMQ-S). FFMQ-S is the shortened version of Five Facet Mindfulness Questionnaire which was first developed by Baer et al., in 2006. The number of items is reduced from 39 to 20 in FFMQ-S, scored from 1 (strongly disagree) to 5 (strongly agree). Five factors are described as (1) Observe (OB), (2) Describe (DS), (3) Nonjudging of inner experience (Nonjudge)/(NJ), (4) Acting with awareness (Actaware)/(AA) and (5) Nonreactivity to Inner Experience (Nonreact)/(NR) (Tran et al., 2013)item fitting, mindfulness in the general population, and on the higher order structure of mindfulness. We derived an alternative two-factor higher order structure for the FFMQ, delineating the attentional and experiential aspects of mindfulness. Method: Data of 640 persons from the Austrian community were used for primary analyses, and data of 333 Austrian students were used for cross-validation. Confirmatory 
analyses and exploratory structural equation modeling (ESEM. Higher scores in each subtest indicate better mindfulness in relevant aspect. Validity and reliability study of Turkish version showed that it is available for use in mindfulness-related researches among Turkish sample (Cronbach's $\alpha=$.71) (Ayalp \& Hisli Şahin, 2018).

Scale for Spiritual Intelligence (SSI). SSI was developed by Kumar \& Mehta in 2013, inspired from a collectivist philosophy based on 5 factors composed of Purpose in life, Human values, Compassion, Commitment towards Humanity, Understanding Self, and Conscience. It is scored on 5-point Likert scale, including 20 items. It was adapted to Turkish by Erduran-Tekin \& Ekşi, 2019098 high school students (440 females and 658 males, with the items reduced to 19 and factors reduced into 4 including understanding self (SU), human values (HV), compassion (CP) and conscience (CS). The total score is obtained by adding the scores from the sub-dimensions. High scores indicate high spiritual intelligence. The reliability and validity findings of adapted scale to Turkish have confirmed the use in scientific studies in Turkish population (Cronbach's $\alpha=.85$ ) (Erduran-Tekin \& Ekşi, 2019)098 high school students (440 females and 658 males.

Hospital anxiety and depression scale (HADS). HADS was first developed by Zigmond \& Snaith in 1983 to measure potential risk of depression and anxiety, based on a self-report of 14 items, 7 items for both subdimensions scored with 4 point Likert scale. This scale is suitable for our research as it measures anxiety and depression risk together through 7 questions for each. It was adapted to Turkish by Aydemir, Güvenir, Küey, \& Kültür in 1997 who suggested the cut-off points for Turkish scale as 10 for anxiety and 7 for depression. It was suggested that it is available for use in mental health research despite its name implying a scale only for hospital. Higher scores of the subscales indicate higher levels of depression and anxiety symptoms. The Turkish adaptation of HADS was found to be valid and reliable in Turkish population (Cronbach's $\alpha=.85$ for depression subscale, .77 for anxiety subscale) (Aydemir Ö, Güvenir T, Küey L, 1997).

\section{Statistical Analysis}

Online and hardcopy data were both entered to the computer software. Scores were carefully installed and scores in reverse items were separately calculated. Descriptive statistics was utilized to reveal the details of sociodemographic profiles. Pearson's correlation analysis was used to discover the relationship between SI \& MF individually, if any exists; and whether these two variables associated with depression and anxiety risk. Lastly, linear regression analysis was applied to significantly correlated subscales to see whether one predicts another. The statistical significance (p) value was set as 0.05 and the statistical equations were conducted with IBM's Statistical Package for the Social Sciences (SPSS). The study was approved by Institutional Review Board of International University of Sarajevo, IUS-REC-01-2995/2019. 


\section{Results}

The total number of participants were 184, composed of 83 males (45.1\%) and 101 females (54.9\%). 46 of all participants were found to be both depressed and anxious when sorted according to cut-off scores of HADS. The participants scored higher than cut-off in only anxiety category were 63 , and 89 participants scored above depression cut-off score, solely. On the other hand, 78 participants were found to be both non-anxious and non-depressed. The frequencies and descriptive statistics were presented in Table 1.

Pearson's correlations were utilized to investigate the presumed association among the scores of 3 scales and coefficients were presented in Table 3. Results indicated that depression and anxiety were positively correlated. In addition, depression scores obtained from HADS are strongly linked with FFMQ-S across all factors in negative direction. Alternatively, when the relationship between anxiety and FFMQ-S was investigated, OB was left out due to insignificance, however, anxiety scores were negatively correlated with the other four factors of FFMQ-S; DS, AA, NJ and NR. Among subscales of SSI, only SU was significantly correlated with depression $(r(182)=.27, \mathrm{p}<.000)$ and anxiety $(r(182)=.23, \mathrm{p}<.002)$, though in a positive direction. Furthermore, negative correlations were found between SU and 3 factors of FFMQ-S; DS, AA and NJ.

Table 1

\begin{tabular}{|c|c|c|c|c|}
\hline & $\mathrm{N}$ & $\%$ & M & $\mathrm{SD}$ \\
\hline Age & 184 & & 23.2 & 4.66 \\
\hline \multicolumn{5}{|l|}{ Gender } \\
\hline Male & 83 & $45.1 \%$ & & \\
\hline Female & 101 & $54.9 \%$ & & \\
\hline \multicolumn{5}{|l|}{ Residency } \\
\hline City Center & 70 & $38 \%$ & & \\
\hline Not city center & 114 & $62 \%$ & & \\
\hline \multicolumn{5}{|l|}{ Employment } \\
\hline Full-time & 17 & $9.2 \%$ & & \\
\hline Part-time & 16 & $8.7 \%$ & & \\
\hline $\begin{array}{l}\text { Unemployed/ } \\
\text { Student }\end{array}$ & 151 & $82.1 \%$ & & \\
\hline \multicolumn{5}{|c|}{ Highest Academic Qualification } \\
\hline Primary School & 3 & $1.6 \%$ & & \\
\hline Middle School & 1 & $5 \%$ & & \\
\hline $\begin{array}{l}\text { Secondary } \\
\text { School }\end{array}$ & 24 & $13 \%$ & & \\
\hline Bachelor & 141 & $76.6 \%$ & & \\
\hline
\end{tabular}


Table 1

\begin{tabular}{|c|c|c|c|c|}
\hline & $\mathrm{N}$ & $\%$ & $\mathrm{M}$ & $\mathrm{SD}$ \\
\hline Master & 15 & $8.2 \%$ & & \\
\hline \multicolumn{5}{|l|}{ Relaxation } \\
\hline Yes & 105 & $57.1 \%$ & & \\
\hline No & 79 & $42.9 \%$ & & \\
\hline \multicolumn{5}{|c|}{ Frequency of Physical Activity } \\
\hline Never & 38 & $20.7 \%$ & & \\
\hline $1-2$ & 78 & $42.4 \%$ & & \\
\hline $2-3$ & 31 & $16.8 \%$ & & \\
\hline $3-4$ & 13 & $7.1 \%$ & & \\
\hline 4 -above & 24 & $13 \%$ & & \\
\hline \multicolumn{5}{|c|}{ Frequency of Spare-time activity } \\
\hline Never & 5 & $6 \%$ & & \\
\hline $1-2$ & 15 & $17 \%$ & & \\
\hline $2-3$ & 13 & $21 \%$ & & \\
\hline $3-4$ & 8 & $25 \%$ & & \\
\hline 4 and above & 22 & $52 \%$ & & \\
\hline \multicolumn{5}{|c|}{ Psychiatric Diagnosis } \\
\hline Yes & 15 & $8.2 \%$ & & \\
\hline No & 169 & $91.8 \%$ & & \\
\hline
\end{tabular}

Descriptive statistics and frequencies for sociodemographic variables

Table 2

Correlations among HADS, SSI and FFMQ-S

\begin{tabular}{|c|c|c|c|c|c|c|c|c|c|c|c|}
\hline Subscales & 1 & 2 & 3 & 4 & 5 & 6 & 7 & 8 & 9 & 10 & 11 \\
\hline 1. Anxiety & - & & & & & & & & & & \\
\hline 2. Depression & $.62^{* *}$ & - & & & & & & & & & \\
\hline 3. Observe $(\mathrm{OB})$ & -.13 & $-.23^{* *}$ & - & & & & & & & & \\
\hline 4. Describe (DS) & $-.26^{* *}$ & $-.31^{* *}$ & .09 & - & & & & & & & \\
\hline 5. Act aware (AA) & $-.41^{* *}$ & $-.36^{* *}$ & .07 & $.31^{* *}$ & - & & & & & & \\
\hline 6. Nonjudge (NJ) & $-.42^{* *}$ & $-.33^{* *}$ & .03 & $.22^{* *}$ & $.28^{* * *}$ & - & & & & & \\
\hline 7. Non-react (NR) & $-.35^{* *}$ & $-.31^{* *}$ & $.25^{* *}$ & $.15^{*}$ & $.20^{* * *}$ & .02 & - & & & & \\
\hline 8. Self-Understanding (SU) & $.27^{* *}$ & $.23^{* *}$ & -.09 & $-.21^{* *}$ & $-.22^{* *}$ & $-.22^{* *}$ & $-.20^{* *}$ & - & & & \\
\hline 9. Human Values (HV) & -.06 & -.05 & -.08 & -.02 & .03 & .05 & .13 & $.15^{*}$ & - & & \\
\hline 10. Compassion (CP) & .07 & .01 & .06 & $-.17^{*}$ & -.12 & -.07 & -.02 & $.61^{* *}$ & $.19^{* *}$ & - & \\
\hline 11. Conscience (CS) & .11 & .07 & -.12 & -.10 & -.03 & $-.15^{*}$ & -.09 & $.44^{* *}$ & $.41^{* *}$ & $.38^{* *}$ & - \\
\hline
\end{tabular}

Note. $N=184$. $* p<.05 * * p<.01$

Linear regression analysis was used with those revealed as statistically significant factors in Pearson's correlation analyses. FFMQ-S's subdimensions and SSI subdimension were entered as predictors (independent variables) to explain the degree and impact on depression and anxiety (dependent variables). For depression, the results have shown that AA (negative), NJ (negative) and NR (negative) were found as predictors (see Table 3), however, OB and DS were not significant. For 
anxiety, DS, AA, NJ and NR were included as potential predictors in linear regression. Similar to the depression results, we have found that AA (negative), NJ (negative) and NR (negative) were strong predictors for anxiety, however, DS was not a significant predictor (see Table 3). SU, subscale of SSI which was found to be positively correlated, was tested for each and it is not a significant predictor for neither depression nor anxiety. When calculated, the regression have displayed a large effect size ( $\mathrm{f}^{2} \geq 0.35$ ), accounting for $29 \%$ of the variation in FFMQ-S predictors with adjusted $\mathrm{R}^{2}=34.8 \%$ (Minton \& Cohen, 1971).

Table 3

Multiple linear regression analysis for HADS and FFMQ-SF subscales

\begin{tabular}{llllllll}
\hline Dependent variable & Predictors & $\mathrm{B}$ & $\mathrm{SE}$ & $\mathrm{Beta}(b)$ & $\mathrm{t}$ & $p$ & $R^{2}$ \\
\hline HADS-Depression & Actaware & -0.19 & 0.06 & -0.19 & -2.78 & 0.006 & $0.29^{* * *}$ \\
& Nonjudge & -0.24 & 0.07 & -0.22 & -3.30 & 0.001 & $0.29^{* * *}$ \\
& Nonreact & -0.23 & 0.08 & -0.19 & -2.84 & 0.005 & $0.29^{* * *}$ \\
HADS-Anxiety & Actaware & -0.21 & 0.06 & -0.23 & -3.49 & 0.001 & $0.36^{* * *}$ \\
& Nonjudge & -0.32 & 0.06 & -0.31 & -4.98 & 0.000 & $0.36^{* * *}$ \\
& Nonreact & -0.31 & 0.07 & -0.27 & -4.33 & 0.000 & $0.36^{* * *}$ \\
\hline
\end{tabular}

Notes for Table 3: HADS: Hospital Anxiety and Depression Scale, FFMQ-SF: Five Facet Mindfulness Questionnaire Short Form

${ }^{*} p<0.05,{ }^{* *} p=0.01, * * * p<0.01$

\section{Discussion}

The initial objective of the study was to identify whether there is a direct relationship between MF, SI, depression and anxiety since several studies have previously suggested high level of associations between these variables among different populations (Agarwal \& Mishra, 2016; Bayrami et al., 2014; Ebrahimi et al., 2012; Hazlett-Stevens, 2012). Four facets of mindfulness seem to appear strongly correlated despite OB remaining as a weak indicator of anxiety similar to those reported by previous studies (Curtiss \& Klemanski, 2014). This may be related to the necessity of cognitive control that is not required during OB activity (Tran et al., 2013)item fitting, mindfulness in the general population, and on the higher order structure of mindfulness. We derived an alternative two-factor higher order structure for the FFMQ, delineating the attentional and experiential aspects of mindfulness. Method: Data of 640 persons from the Austrian community were used for primary analyses, and data of 333 Austrian students were used for cross-validation. Confirmatory analyses and exploratory structural equation modeling (ESEM. As previously mentioned, the effects of MF vary depending on prior experience of MF or meditation suggested by Baer et al. (2008), among nonmeditators OB may even serve as rumination - focusing and/or rethinking pattern towards one's own distress (Susan Nolen-Hoeksema et al., 1997). Besides, DS and AA are likely to be complementary as conducting the describing process requires internal or external awareness, which may supply the tools to keep self-judgement objectively intact. Therefore, negative correlation of both with anxiety and depression is easily understandable. Moreover, NJ and NR 
referring nonreactive and nonjudgmental stance towards inner sensations seem to be associated with higher risk of depression and anxiety, potentially due to lack of coping mechanisms with ruminating thoughts. These results also corroborate the previous findings toward NJ and NR (Bohlmeijer et al., 2011).

Furthermore, considering SI finding and lack of evidence for hypothesis; a possible explanation for having only one-dimensional support towards previous literature might be the use of different scales which vary in nature and structure. In addition, the mean values of SI subscales in this study also differed from previous studies, for instance; mean values of subscales in Erduran-Tekin \& Ekşi (2019)098 high school students (440 females and 658 males were much higher in comparison to ours, this data suggests that our participants were generally lower in SI which might be the reason due to which the association between SI and MF failed to be significant. On top of that, our participants were predominantly students and SI is inherently related to growth, therefore adolescents are likely to score less (Kumar \& Mehta, 2011) which may explain our findings that SI with no association. It is interesting that we found a negative correlation between SU subscale, depression, and anxiety. SU items are based on one's understanding of self, very much similar to the term of rumination. Both appears to involve with certain degree of investigation towards oneself and the evidence presented thus far supports the idea that rumination predicts anxiety and depression symptoms (S. Nolen-Hoeksema, 2000; Vanderhasselt et al., 2016).

The generalizability of these findings is subject to certain limitations. First, the scope of this study was limited due to the cross-sectional design which disables conclusions on causality. Another source of weakness in this study which could have affected the measurements of variables was the use of self-report questionnaires which poses validity concerns for our findings. Additionally, it is unfortunate that the study did not include participants with diverse ages. The small sample size and the limited age range distribution did not allow broader ground of accuracy; therefore, the current results are mainly generalizable to student population in bachelor years. Including more adults in the study may have created larger representable results in terms of the correlation particularly with SI.

In conclusion, our findings provide empirical support for previously suggested associations between MF and depression \& anxiety (Hofmann et al., 2010; Marchand, 2012; Song \& Lindquist, 2015; Soysa, C.K., Wilcomb, 2013). In addition, there are several studies investigating the effectiveness of MF-integrated therapy approaches (Garland et al., 2018; Manicavasgar et al., 2011; Woolhouse et al., 2012)Therefore, our study may be useful for further strategies of MF integration in the scope of current interventions. Future studies with greater sample and age variety are needed to investigate SI and MF relationship in-depth. 


\section{Acknowledgement}

The study was approved by Institutional Review Board of International University of Sarajevo, with the official permission registered as IUS-REC-01-2995/2019. All procedures followed were in accordance with the ethical standards of the responsible committee on human experimentation (institutional and national) and with the Helsinki Declaration of 1975, as revised in 2000.

Funding source: There was no funding source used for this study.

Conflict of interest: Pınar Ünal-Aydın, Yasin Arslan, and Orkun Aydın declare that they have no conflicts of interest.

All procedures followed were in accordance with the ethical standards of the responsible committee on human experimentation (institutional and national) and with the Helsinki Declaration of 1975, as revised in 2000. Informed consent was obtained from all participants for being included in the study.

Author Contributions: Conceptualization: Orkun Aydın, Pınar Ünal-Aydın. Data curation: Yasin Arslan Formal analysis: Orkun Aydın. Investigation: Orkun Aydın, Yasin Arslan. Methodology: Orkun Aydın, Pınar Ünal-Aydın. Supervision: Orkun Aydın. Writing — Original draft: Yasin Arslan. Writing—Review \& editing: Pınar Ünal-Aydın.

\section{References}

Agarwal, S., \& Mishra, P. C. (2016). Relationship between mindfulness and spiritual intelligence among bank employees. Indian Journal of Positive Psychology, 7(3), 356-358. http://search. ebscohost.com/login.aspx?direct=true $\& \mathrm{db}=$ asn \&AN=119265710\&site=ehost-live

Airaksinen, E., Larsson, M., Lundberg, I., \& Forsell, Y. (2004). Cognitive functions in depressive disorders: Evidence from a population-based study. Psychological Medicine, 34(1), 83-91. https://doi.org/10.1017/S0033291703008559

Allen, N. B., Chambers, R., Knight, W., Blashki, G., Ciechomski, L., Hassed, C., Gullone, E., McNab, C., \& Meadows, G. (2006). Mindfulness-based psychotherapies: A review of conceptual foundations, empirical evidence and practical considerations. Australian and New Zealand Journal of Psychiatry, 40(4), 285-294. https://doi.org/10.1111/j.1440-1614.2006.01794.x

Amram, Y., \& Dryer, D. C. (2008). The Integrated Spiritual Intelligence Scale (ISIS): development and preliminary validation. 116th Annual Conference of the American Psychological Association, 1-46.

Association, A. P. (2013). Diagnostic and statistical manual of mental disorders (DSM-5®). Washington, DC: Publisher.

Ayalp, H. D., \& Hisli Şahin, N. (2018). Beş Faktörlü Bilgece Farkındalık Ölçeği-Kısa Formu'nun (BFBFÖ-K) Türkçe Uyarlaması. Klinik Psikoloji Dergisi, 2(3), 117-127.

Aydemir Ö, Güvenir T, Küey L, K. S. (1997). Hastane Anksiyete ve Depresyon Ölçeği Türkçe formunun geçerlilik ve güvenilirliği. Reliability and Validity of the Turkish version of Hospital Anxiety and Depression Scale. Türk Psikiyatri Dergisi, 8(4), 280-287. 
Baer, R. A., Smith, G. T., Hopkins, J., Krietemeyer, J., \& Toney, L. (2006). Using self-report assessment methods to explore facets of mindfulness. Assessment, 13(1), 27-45. https://doi. org/10.1177/1073191105283504

Baer, R. A., Smith, G. T., Lykins, E., Button, D., Krietemeyer, J., Sauer, S., Walsh, E., Duggan, D., \& Williams, J. M. G. (2008). Construct validity of the five facet mindfulness questionnaire in meditating and nonmeditating samples. Assessment, 15(3), 329-342. https://doi. org/10.1177/1073191107313003

Bandelow, B., \& Michaelis, S. (2015). Epidemiology of anxiety disorders in the 21st century. Dialogues in Clinical Neuroscience, 17(3), 327.

Barnes, S., \& Lynn, S. (2010). Mindfulness Skills and Depressive Symptoms: A Longitudinal Study. Imagination, Cognition and Personality, 30, 77-91. https://doi.org/10.2190/IC.30.1.e

Bayrami, M., Movahedi, Y., \& Movahedi, M. (2014). The role of spiritual intelligence in perceived stress, anxiety and depression of Lorestan medical university students (Iran). Journal of Babol University of Medical Sciences, 16(1), 56-62.

Bishop, S. R., Lau, M., Shapiro, S., Carlson, L., Anderson, N. D., Carmody, J., Segal, Z. V., Abbey, S., Speca, M., Velting, D., \& Devins, G. (2004). Mindfulness: A proposed operational definition. Clinical Psychology: Science and Practice, 11(3), 230-241. https://doi.org/10.1093/clipsy/bph077

Bohlmeijer, E., Klooster, P. M., Fledderus, M., Veehof, M., \& Baer, R. (2011). Psychometric properties of the five facet mindfulness questionnaire in depressed adults and development of a short form. Assessment, 18(3), 308-320. https://doi.org/10.1177/1073191111408231

Cardaciotto, L., Herbert, J. D., Forman, E. M., Moitra, E., \& Farrow, V. (2008). The assessment of present-moment awareness and acceptance: The philadelphia mindfulness scale. Assessment, 15(2), 204-223. https://doi.org/10.1177/1073191107311467

Castaneda, A. E., Tuulio-Henriksson, A., Marttunen, M., Suvisaari, J., \& Lönnqvist, J. (2008). A review on cognitive impairments in depressive and anxiety disorders with a focus on young adults. Journal of Affective Disorders, 106(1-2), 1-27. https://doi.org/10.1016/j.jad.2007.06.006

Chambers, R., Lo, B. C. Y., \& Allen, N. B. (2008). The impact of intensive mindfulness training on attentional control, cognitive style, and affect. Cognitive Therapy and Research, 32(3), 303322. https://doi.org/10.1007/s10608-007-9119-0

Curtiss, J., \& Klemanski, D. H. (2014). Factor Analysis of the Five Facet Mindfulness Questionnaire in a Heterogeneous Clinical Sample. Journal of Psychopathology and Behavioral Assessment, 36(4), 683-694. https://doi.org/10.1007/s10862-014-9429-y

Ebrahimi, A., Keykhosrovani, M., Dehghani, M., \& Javdan, M. (2012). Investigating the relationship between resiliency, spiritual intelligence and mental health of a group of undergraduate students. In Life Science Journal (Vol. 9, Issue 1, pp. 67-70). http://www.lifesciencesite.com/lsj/life0901 //012_7889life0901_67_70.pdf

Erduran-Tekin, Ö., \& Ekşi, H. (2019). Adapting the Scale for Spiritual Intelligence to Turkish. Spiritual Psychology and Counseling, 4(2), 123-141.https://doi.org/10.37898/spc.2019.4.2.0062

Frewen, P. A., Evans, E. M., Maraj, N., Dozois, D. J. A., \& Partridge, K. (2008). Letting go: Mindfulness and negative automatic thinking. Cognitive Therapy and Research, 32(6), 758774. https://doi.org/10.1007/s10608-007-9142-1 
Garland, E. L., Roberts-Lewis, A., Tronnier, C. D., Graves, R., \& Kelley, K. (2018). Corrigendum to "Mindfulness-oriented recovery enhancement versus CBT for co-occurring substance dependence, traumatic stress, and psychiatric disorders: Proximal outcomes from a pragmatic randomized trial" [Behav. Res. Ther. 77 (2016) 7-16] (S000579671530. Behaviour Research and Therapy, 100, 78. https://doi.org/10.1016/j.brat.2017.09.007

Gothe, N., Pontifex, M. B., Hillman, C., \& McAuley, E. (2013). The Acute Effects of Yoga on Executive Function. Journal of Physical Activity and Health, 10(4), 488-495. https://doi. org/10.1123/jpah.10.4.488

Hazlett-Stevens, H. (2012). Mindfulness-based stress reduction for comorbid anxiety and depression: Case report and clinical considerations. Journal of Nervous and Mental Disease, 200(11), 999-1003. https://doi.org/10.1097/NMD.0b013e3182718a61

Hofmann, S. G., Andreoli, G., Carpenter, J. K., \& Curtiss, J. (2016). Effect of Hatha yoga on anxiety: a meta-analysis. Journal of Evidence-Based Medicine, 9(3), 116-124. https://doi. org/10.1111/jebm.12204

Hofmann, S. G., Sawyer, A. T., Witt, A. A., \& Oh, D. (2010). The Effect of Mindfulness-Based Therapy on Anxiety and Depression: A Meta-Analytic Review. Journal of Consulting and Clinical Psychology, 78(2), 169-183. https://doi.org/10.1037/a0018555

Jha, A. P., Krompinger, J., \& Baime, M. J. (2007). Mindfulness training modifies subsystems of attention. Cognitive, Affective and Behavioral Neuroscience, 7(2), 109-119. https://doi. org/10.3758/CABN.7.2.109

Koenig, H. G. (2009). Research on religion, spirituality, and mental health: A review. Canadian Journal of Psychiatry, 54(5), 283-291. https://doi.org/10.1177/070674370905400502

Kumar, V. V., \& Mehta, M. (2011). Scale for Spiritual Intelligence. In PsycTESTS (Issue June 2013). https://doi.org/10.1037/t16725-000

Manicavasgar, V., Parker, G., \& Perich, T. (2011). Mindfulness-based cognitive therapy vs cognitive behaviour therapy as a treatment for non-melancholic depression. Journal of Affective Disorders, 130(1-2), 138-144. https://doi.org/10.1016/j.jad.2010.09.027

Marchand, W. R. (2012). Mindfulness-based stress reduction, mindfulness-based cognitive therapy, and zen meditation for depression, anxiety, pain, and psychological distress. Journal of Psychiatric Practice, 18(4), 233-252. https://doi.org/10.1097/01.pra.0000416014.53215.86

Minton, P. D., \& Cohen, J. (1971). Statistical Power Analysis for the Behavioral Sciences. Journal of the American Statistical Association, 66(334), 428. https://doi.org/10.2307/2283959

Nolen-Hoeksema, S. (2000). The role of rumination in depressive disorders and mixed anxiety/ depressive symptoms. Journal of Abnormal Psychology, 109(3), 504-511. https://doi. org/10.1037/0021-843X.109.3.504

Nolen-Hoeksema, Susan, McBride, A., \& Larson, J. (1997). Rumination and psychological distress among bereaved partners. Journal of Personality and Social Psychology, 72(4), 855-862. https://doi.org/10.1037/0022-3514.72.4.855

Song, Y., \& Lindquist, R. (2015). Effects of mindfulness-based stress reduction on depression, anxiety, stress and mindfulness in Korean nursing students. Nurse Education Today, 35(1), 8690. https://doi.org/10.1016/j.nedt.2014.06.010

Soysa, C.K., Wilcomb, C. J. (2013). Mindfulness, Self-compassion, Self-efficacy, and Gender as Predictors of Depression, Anxiety, Stress, and Well-being. Mindfulness, 6, 217-226. https://doi. org/10.1007/s12671-013-0247-1 
Streeter, C. C., Theodore, H. W., Owen, L., Rein, T., Karri, S. K., Yakhkind, A., Perlmutter, R., Prescot, A., Renshaw, P. F., Ciraulo, D. A., \& Jensen, J. E. (2010). Effects of yoga versus walking on mood, anxiety, and brain GABA levels: A randomized controlled MRS study. Journal of Alternative and Complementary Medicine, 16(11), 1145-1152. https://doi.org/10.1089/ acm.2010.0007

Tang, Y. Y., Yang, L., Leve, L. D., \& Harold, G. T. (2012). Improving Executive Function and Its Neurobiological Mechanisms Through a Mindfulness-Based Intervention: Advances Within the Field of Developmental Neuroscience. Child Development Perspectives, 6(4), 361-366. https:// doi.org/10.1111/j.1750-8606.2012.00250.x

Tran, U. S., Glück, T. M., \& Nader, I. W. (2013). Investigating the Five Facet Mindfulness Questionnaire (FFMQ): Construction of a Short Form and Evidence of a Two-Factor Higher Order Structure of Mindfulness. Journal of Clinical Psychology, 69(9), 951-965. https://doi. org/10.1002/jclp.21996

Vanderhasselt, M. A., Brose, A., Koster, E. H. W., \& De Raedt, R. (2016). Co-variation between stressful events and rumination predicts depressive symptoms: An eighteen months prospective design in undergraduates. Behaviour Research and Therapy, 87, 128-133. https://doi. org/10.1016/j.brat.2016.09.003

Vos, T., Barber, R. M., Bell, B., Bertozzi-Villa, A., Biryukov, S., Bolliger, I., Charlson, F., Davis, A., Degenhardt, L., \& Dicker, D. (2015). Global, regional, and national incidence, prevalence, and years lived with disability for 301 acute and chronic diseases and injuries in 188 countries, 1990-2013: a systematic analysis for the Global Burden of Disease Study 2013. The Lancet, 386(9995), 743-800.

Woolhouse, H., Knowles, A., \& Crafti, N. (2012). Adding mindfulness to CBT programs for binge eating: A mixed-methods evaluation. Eating Disorders, 20(4), 321-339. https://doi.org/10.108 0/10640266.2012.691791

Wu, Z., \& Fang, Y. (2014). Comorbidity of depressive and anxiety disorders: challenges in diagnosis and assessment. Shanghai Archives of Psychiatry, 26(4), 227-231. https://doi.org/10.3969/j. issn.1002-0829.2014.04.006

Zeidan, F., Johnson, S. K., Diamond, B. J., David, Z., \& Goolkasian, P. (2010). Mindfulness meditation improves cognition: Evidence of brief mental training. Consciousness and Cognition, 19(2), 597-605. https://doi.org/10.1016/j.concog.2010.03.014

Zigmond, A. S., \& Snaith, R. P. (1983). The hospital anxiety and depression scale. Acta Psychiatrica Scandinavica, 67(6), 361-370. 
